\title{
FURTHER DATA ON THE BELL CHEMISTRY TEST
}

\author{
HENRY L. GERRY \\ Worcester Academy, Worcester, Massachusetts
}

A recent article by Professor Thomas H. Briggs' ${ }^{1}$ of Columbia, suggesting that the original standards set by the author of the Bell Chemistry Test ${ }^{2}$ may be too low, has stimulated the writer of this paper to offer the results of his use of the Bell Test in support of the position of Doctor Briggs. The basis of this report is in records made by two groups of pupils; one in the Biddeford (Maine) High School and one at Worcester Academy. Group I was a class of twenty-two high school Juniors, fourteen boys and eight girls, who were tested near the completion of nine months of study of chemistry. Group II

\section{TABLE I}

Scores in Bell chemistry test

\begin{tabular}{|c|c|c|}
\hline \multirow[b]{2}{*}{ Score } & \multicolumn{2}{|c|}{ Number of pupils } \\
\hline & $\begin{array}{c}\text { Group I } \\
\text { Nine months of training } \\
\text { under a teacher with one } \\
\text { year's experience }\end{array}$ & $\begin{array}{l}\text { Group II } \\
\text { After six months of study }\end{array}$ \\
\hline $\begin{array}{c}\text { below } 50 \\
50-54 \\
55-59 \\
60-64 \\
65-69 \\
70-74 \\
75-79 \\
80-84 \\
85-89 \\
90 \text { and above }\end{array}$ & $\begin{array}{l}3 \\
0 \\
4 \\
3 \\
2 \\
3 \\
5 \\
1 \\
0 \\
1\end{array}$ & $\begin{array}{l}1 \\
3 \\
3 \\
1 \\
4 \\
0 \\
6 \\
4 \\
1 \\
2\end{array}$ \\
\hline Total............... & 22 & 25 \\
\hline Median. ........... & 68 & 75 \\
\hline Average............. & 65.7 & 70.1 \\
\hline
\end{tabular}

1 Journal of Educational Psychology, 11:224-8.

Id. 9: 199-209. School of Science and Mathematics, 18:425-32. 
was a group of twenty-five boys, mostly Seniors, tested after six months of training. The first group was taught by a man with one year's experience; the second, by the writer. The distribution of scores is shown in Table I.

These two sets of papers were marked before the publication of the acceptable answers, ${ }^{1}$ yet there was so close an agreement between the set used and the published set that the resulting scores are not seriously affected by the minor differences. The differences that existed were of such a nature as to reduce slightly the scores of Groups I and II below what they would have been had the published answers been available. These two groups were made up of unselected pupils from two types of New England secondary schools, subjected to the Bell Test without warning. Therefore, the results may be deserving of consideration in arriving at a final standard.

For purposes of convenient comparison, these results are shown with those of Bell and Briggs in Table II.

TABLE II

Results of Bell chemistry test

\begin{tabular}{|c|c|c|}
\hline \multirow{2}{*}{ Group } & \multicolumn{2}{|c|}{ Scores } \\
\hline & Median & Average \\
\hline $\begin{array}{l}\text { Three hundred thirty-seven pupils in fourteen Texas } \\
\text { High Schools }{ }^{2} . \ldots \ldots \ldots \ldots \ldots \ldots . \ldots\end{array}$ & & 59 \\
\hline $\begin{array}{c}\text { Twenty-seven pupils in Resding (Pa.) Boys' High } \\
\text { School'. } \\
\text { Sc. }\end{array}$ & 57.25 & 57.96 \\
\hline Eleven pupils in Horace Mann School for Boys' ... . . . & 82.5 & 7909 \\
\hline Twenty-two pupils in Biddeford (Me.) High School. ... & 68 & 65.7 \\
\hline Twenty-five boys in Worcester (Mass.) Academy...... & 75 & 70.1 \\
\hline
\end{tabular}

The relative difficulty of the twenty-five questions may be judged from Table III.

Table III is read as follows: The easiest question (i.e., the one receiving a correct answer from the largest per cent of pupils) was number one (What chemicals are liberated in the electrolysis of water?) for the pupils of fourteen Texas high schools after eight months of training; number fourteen (Name the two most abundant elements in the atmosphere) for the Biddeford High School Juniors after nine months of study; and number one for the Worcester Academy Seniors who had studied Chemistry six months. The next to the easiest 
TABLE III

Relative difficulty of questions in Bell chemistry test as judged from the per cent of students giving correct answers.

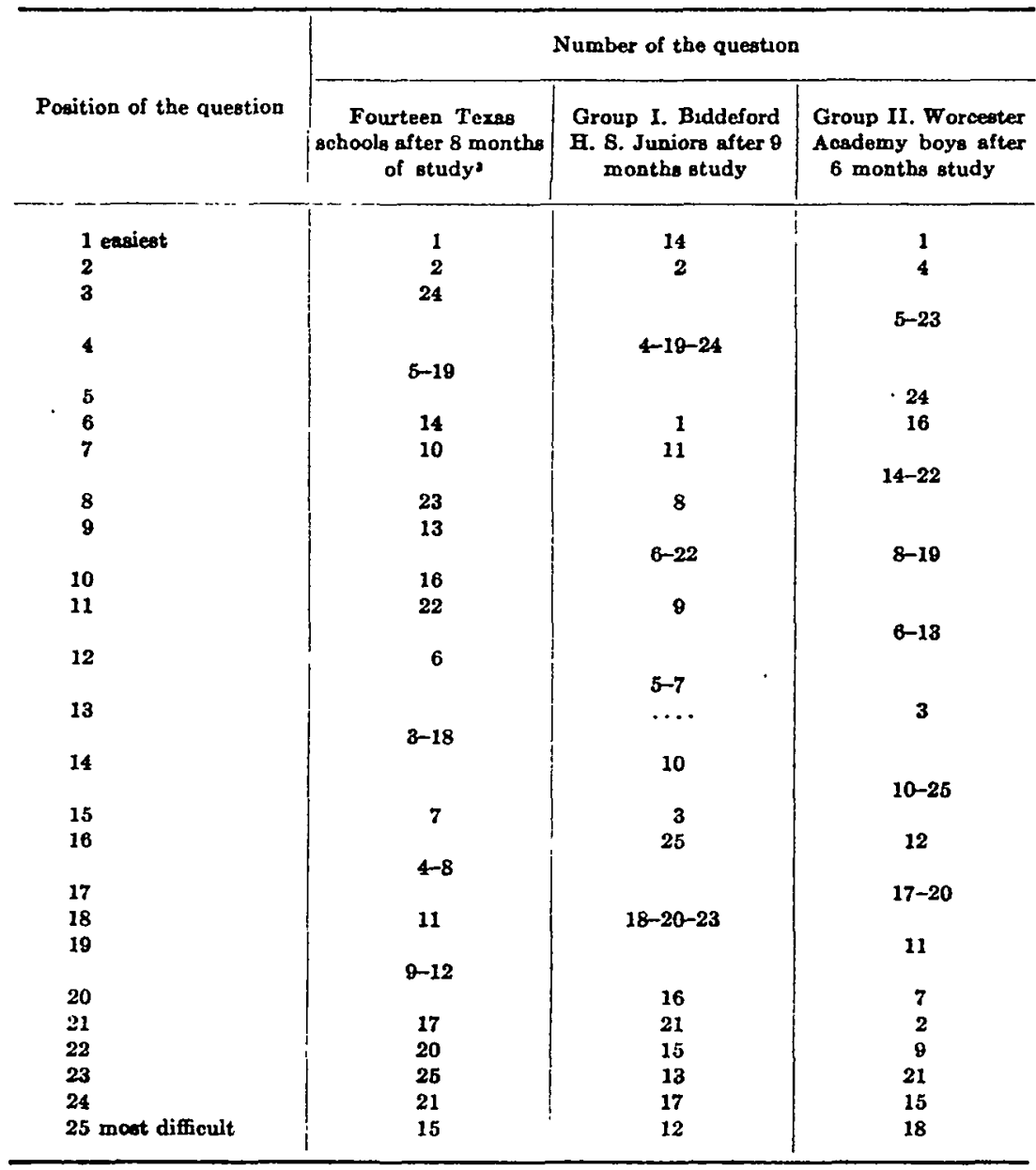

3. From tables I and III, Journal of Educational Psychology, $9: 199-209$.

question was number two (What gas is given off by the action of yeast in bread dough?) for the two high school groups and number four (Express in cubic centimeters one liter) for the Worcester Academy boys, etc.

In this table it will be noted that of the easiest seven questions for the Texas group, five were among the easiest seven for Group I; 
and four, for Group II. Of the most difficult seven questions for the Texas group five are found among the most difficult seven for Group I and only three for Group II. The correlations in these three cases, calculated according to the Pearson method are found in Table IV.

TABLE IV

Grade-position correlstions for the twenty-five questions of the Bell chemistry test.

\begin{tabular}{|c|c|}
\hline Groups correlated & $r$ \\
\hline 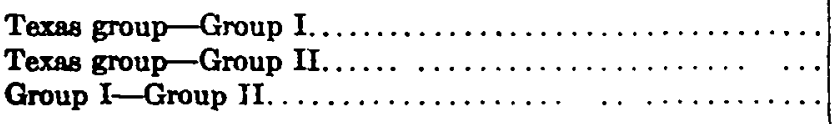 & $\begin{array}{l}.63 \\
.61 \\
.42\end{array}$ \\
\hline Average..... & .55 \\
\hline
\end{tabular}

